\title{
Memahami Organisasi untuk Keunggulan Bersaing (Kajian Manajemen Strategi di Sekolah)
}

\section{Salisman}

Pascasarjana Universitas Halu Oleo email: salismanalisyanadia@gmail.com

\begin{abstract}
Abstrak
Sekolah sebagai wahana pembentukan manusia paripurna harus senantiasa melakukan perbaikan secara berkelanjutan. Tata kelola sekolah yang baik menjadi penopang utama dalam melaksanakan agenda-agenda pendidikan dan pembelajaran. Tidak hanya untuk kepentingan sementara, lebih penting lagi untuk masa depan yang lebih panjang. Posisi kepala sekolah sangat penting dalam memahami internal dan eksternal organisasi, sehingga dapat merumuskan posisi sekolah di masa depan dan menciptakan keunggulan-keunggulan khas sekolahnya.
\end{abstract}

Kata Kunci: Manajemen Strategi, Organisasi, Kepala Sekolah, Keunggulan Bersaing

\section{Understanding Organizations for Competitive Advantages (Strategic Management Study in Schools)}

\begin{abstract}
School as a vehicle for the formation of a complete human being must always make continuous improvements Good school governance is the main support in implementing education and learning agendas. Not only for temporary purposes, more importantly for a longer future. The position of the principal is very important in understanding the internal and external organization, so that it can formulate a school position in the future and create distinctive advantages of the school.
\end{abstract}

\section{Keywords: Management Strategy, Organization, Principal,} Competitive Advantage 


\section{Pendahuluan}

Berbagai lembaga pada dasarnya ingin bertahan (survive) dalam persaingan antar lembaga. Meskipun demikian, tidak semua lembaga dapat mewujudkan keinginan tersebut. Penyebab bubarnya sebuah organisasi biasanya ketika organisasi tersebut kehilangan relevansi kekinian, dan kegagalan meneropong masa depan. Akibatnya adalah kebingungan dalam menyesuaikan diri, apalagi dalam derap perubahan yang sangat cepat. Secara sederhana, fenomena ini dapat dikatakan sebagai ketidakpahaman pengelola terhadap organisasi yang dikelolanya.

Secara garis besar, organisasi terdiri dari sisi internal dan eksternal. Variabel manusia, regulasi, metode, budaya, dan produk adalah sisi internal yang mesti diperhatikan oleh pimpinan lembaga, termasuk lembaga pendidikan. Secara internal variabel-variabel di atas harus mendapatkan perlakuan khusus agar adaptif dengan perkembangan. Pada sisi eksternal, pimpinan sekolah harus membuka pandangan secara luas mengenai kondisi masyarakat, kebutuhan pelanggan, sistem pengelolaan sekolah terkini, dan membaca peta persaingan sekolah. Dengan memahami kedua sisi tersebut selanjutnya dapat dirumuskan agenda-agenda berjangka, mulai jangka pendek, menengah, dan jangka panjang. Cara pikir demikian telah mengantarkan seorang kepala sekolah pada cara berpikir manajemen strategik. Tujuannya adalah meraih keunggulan bersaing (competitive advantage).

\section{Pengertian Manajeman Strategi}

Manajeman strategi adalah suatu rencana yang disusun dan dikelola dengan memperhitungkan berbagai sisi dengan tujuan agar pengaruh rencana tersebut bisa memberikan dampak positif bagi organisasi tersebut secara jangka panjang. ${ }^{1}$

Wheelen dan Hunger mengemukaan manajemen strategik adalah serangkaian keputusan dan tindakan manajerial yang menentukan kinerja perusahaan dalam jangka panjang. Manajemen strategik meliputi pengamatan lingkungan, perumusan strategi (perencanaan strategik atau perencanaan jangka panjang) evaluasi dan pengendalian. Manajemen Strategi adalah sekumpulan keputusan dan tindakan yang menghasilkan perumusan (formulating) dan

\footnotetext{
${ }^{1}$ Irham Fahmi, Manajeman Strategis, (Bandung : Alfabeta, 2015) h. 2
} 
pelaksanaan (implementasi) rencana-rencana yang dirancang untuk mencapai sasaran-sasaran perusahaan. ${ }^{2}$

Grant, Strategi juga dapat diartikan sebagai keseluruhan rencana mengenai penggunaan sumber daya-sumber daya untuk menciptakan suatu posisi menguntungkan. Dengan kata lain, manajamen strategis terlibat dengan pengembangan dan implementasi strategi-strategi dalam kerangka pengembangan keunggulan bersaing. ${ }^{3}$

Menurut Wahyudi manajemen strategik adalah suatu seni dan ilmu dari perumusan (formulating), penerapan (implementing), dan evaluasi (evaluating) keputusan-keputusan strategis antar fungsifungsi yang memungkinkan sebuah organisasi mencapai tujuan-tujuan masa mendatang. ${ }^{4}$ Manajemen Strategik menurut Flavel dan Williams adalah sebagai keseluruhan sistem manajemen, dimana didalamnya terkandung formulasi, implementasi dan evaluasi guna mencapai hasil yang realistis dan obyektif. ${ }^{5}$

Berdasarkan beberapa pendapat di atas maka dapat di tarik kesimpulan bahwa manajeman strategi adalah suatu rangkaian kegiatan yang dilakukan mulai dari pengamatan linkungan, perumusan strategi, penerapan, dan evaluasi di sekolah, yang dilakukan untuk mencapai tujuan di masa yang akan datang.

\section{Dimensi-Dimensi Manajemen Strategik}

Berdasarkan pengertian dan karakteristiknya dapat disimpulkan bahwa manajemen strategik memiliki beberapa dimensi atau bersifat multidimensional. Dimensi-dimensi yang dimaksud adalah :

1. Dimensi Keterlibatan Manajemen Puncak

Salah satu sifat keputusan strategik ialah bahwa keputusan tersebut menyangkut seluruh segi organisasi. Karena hanya pada tingkat manajemen puncaklah akan tampak segala bentuk implikasi dan remifikasi berbagai tantangan dan tuntutan lingkungan internal

${ }^{2}$ Husein Umar, Desain Penelitian Manajemen Strategik (Jakarta: PT. Raja Grafindo Persada. 2010), h. 16.

3 Abdul Muchlis, Implementasi Manajeman Strategi Dalam Upaya Peningkatan Mutu Pendidikan, (Fakultas Dakwah: Jurusan Manajeman Dakwah)

${ }^{4}$ Akdon, Strategic Management for Educational Management. (Bandung: Alfabeta 2011), h. 5

${ }^{5}$ Hassel Nogi S. Tangkilisan, Manajemen Modern untuk Sektor Public, (Yogyakarta: Balairung, 2003), h. 9 
dan eksternal yang sangat mungkin tidak terlihat oleh para manajer tingkat yang lebih rendah. Selain itu hanya manajemen puncaklah yang memiliki wewenang untuk mengalokasikan sarana, prasarana, dan sumber lainnya yang diperlukan untuk mengimplementasikan keputusan yang telah diambil.

2. Dimensi Alokasi Dana, Sarana dan Prasarana

Disini manajemen puncak berperan selaku integrator dari berbagai satuan kerja yang merasa berhak atas pengelolaan dana, sarana, prasarana maupun tenaga kerja dari satuan-satuan kerja lainnya dalam organisasi. Hal ini tergantung pada sifat penugasan, sasaran dan pembatasan waktu, mungkin saja satu satuan kerja diperlukan sebagai "yang terpenting" pada momen tertentu, tetapi pada momen lain satuan kerja lainlah yang bersifat strategik.

3. Dimensi Waktu Keputusan Strategik

Salah satu ciri keputusan strategik ialah jangkauan waktunya yang relatif jauh kedepan, apakah itu lima tahun ataupun sepuluh tahun, bahkan bisa lebih. Penting untuk diperhatikan bahwa sekali manajemen puncak membuat suatu keputusan strategik, atas dasar keputusan itulah citra organisasi diciptakan dan dipelihara.

4. Dimensi Orientasi Masa Depan

Disini sebuah organisasi membutuhkan seorang manajer handal yang memiliki sikap antisipatif dan proaktif. Karena dengan sikap yang antisipatif dan proaktif, manajemen akan lebih siap menghadapi tanggapan perubahan yang akan terjadi dan tidak akan dihadapkan kepada situasi "dadakan".

5. Konsekuensi Isu Strategik Yang Multifaset

Salah satu dimensi keputusan strategik ialah bersifat integratif dan koordinatif, karena keputusan strategik biasanya menjangkau semua komponen atau unsur organisasi.

6. Dimensi Lingkungan Eksternal

Suatu organisasi biasanya mempengaruhi lingkungannya dan pasti dipengaruhi oleh kondisi eksternal yang faktor-faktornya umumnya berada diluar kendali organisasi yang bersangkutan. Untuk itu agar organisasi berhasil meraih keberhasilan yang di dambakannya dimasa depan faktor- faktor eksternal tersebut harus diperhitungkan dengan matang ${ }^{6}$.

\footnotetext{
${ }^{6}$ Sondang P. Siagian, Manajemen Strategik (Jakarta: Bumi Aksara, 2001),
} h. $18-20$ 


\section{Manfaat Manajemen Strategik}

Dengan menggunakan Manajemen Strategik, para manajer di semua tingkat dalam perusahan berinteraksi dalam perencanaan dan implementasi. ${ }^{7}$ Dengan menggunakan Manajemen Strategik sebagai instrumen untuk mengantisipasi perubahan lingkungan sekaligus sebagai kerangka kerja untuk menyelesaikan setiap masalah melalui pengambilan keputusan perusahaan, maka penerapan Manajemen Strategik dalam suatu organisasi/perusahaan diharapkan akan membawa manfaat-manfaat sebagai berikut:

1. Memberikan arah jangka panjang yang akan dituju

2. Membantu organisasi beradaptasi pada perubahan-perubahan yang terjadi

3. Membuat suatu organisasi menjadi lebih efektif

4. Mengidentifikasi keunggulsn komparatif suatu organisasi dalam lingkungan yang semakin beresiko.

5. Aktivitas pembuatan strategi akan mempertinggi kemampuan perusahaan (organisasi) untuk mencegah munculnya masalah dimasa dating

6. Keterlibatan karyawan dalam pembuatan strategi aksn lebih memotivasi mereka pada tahap pelaksanaannya

7. Aktivitas yang tumpang tindih akan dikurangi

8. Keengganan untuk berubah dari karyawan lama dapat dikurangi. ${ }^{8}$

Manajemen Strategi semakin penting arti dan manfaatnya apabila diingat bahwa lingkungan perusahaan (organisasi) mengalami perubahan yang semakin cepat dan kompleks, dimana dibutuhkan suatu pemikiran strategi dari para pemimpin untuk mengelola perubahan yang ada dalam suatu strategi yang tepat dan handal sehingga keberhasilan Manajemen Strategi ditentukan oleh para manajer/pimpinannya.

\section{Strategik Formulasi, Implementasi dan Evaluasi}

Manajemen strategik merupakan suatu proses terus-menerus dan walaupun pada waktunya harus dipilih titik-titik yang berlainan dengan maksud untuk mengambil keputusan. Selanjutnya, dari definisi atau pengetahuan manajemen strategik sebagaimana yang telah diuraikan sebelumnya, dapat difahami bahwa manajemen

\footnotetext{
${ }^{7}$ Robinson Pearce, Manajemen, h. 30

${ }^{8}$ Agustinus Sri Wahyudi, Manajemen, h. 19
} 
strategik terdiri atas tiga macam proses manajemen. ${ }^{9}$ Pertama, Strategi formulasi (Strategi Formulation) yaitu langkah dalam merumuskan strategi. Prosedur ini sering juga disebut dengan istilah perencanaan strategik (Strategic Planning). Kedua, Strategi implementasi (strategic Implementation) yaitu tahap pelaksanaan atau penerapan strategi-strategi yang telah dirumuskan. Ketiga, Pengawasan strategik (Control Strategic) yaitu usaha-usaha untuk memonitor seluruh hasil dan pembuatan strategi. ${ }^{10}$

Uraian tentang ketiga proses manajemen tersebut adalah sebagai berikut:

1. Formulasi Strategi

Strategi formulasi atau perumusan strategi memedomani ekskutif dalam menetapkan bidang usaha yang diterjuni perusahaan (organisasi), tujuan akhir (aims) yang ingin dicapainya, serta cara yang akan digunakan untuk mencapai tujuan akhir tersebut. ${ }^{11}$

Pada tahap pertama ini terdapat 2 (dua) langkah sebagai berikut:

a. Analisis Lingkungan

Lingkungan adalah salah satu fator terpentig untuk menunjang keberhasilan perusahaan dalam persaingan. ${ }^{12}$ Untuk membuat tujuan, sasaran dan strategi-strategi yang akan diambil, diperlukan analisis yang mendalam dan menyeluruh mengenai lingkungan dimana lembaga itu berada. Ada dua faktor yang membuat analisis lingkungan menjadi suatu analisis penting dalam manajemen strategik dan harus dilakukan oleh kepala sekolah:

1) Bahwa organisasi tidak berdiri sendiri (terisolasi) tetapi berinteraksi dengan bagian-bagian dari lingkungan dan lingkungan itu sendiri berubah setiap saat.

2) Pengaruh yang sangat rumit dan kompleks dapat mempengaruhi kinerja banyak bagian yang berbeda sebuah perusahaan. ${ }^{13}$

Analisis lingkungan secara garis besar terdapat dua bagian. Pertama, Analisis lingkungan internal terkait dengan melihat kedalam organisasi yaitu melihat bagaimana kekuatan (Strength) dan

\footnotetext{
${ }^{9}$ Karhi Nisjar, Manajemen, h. 85

${ }^{10}$ Ibid, h. 86

${ }^{11}$ Robinson Pearce, Manajemen, h. 53

${ }^{12}$ Agustius Sri Wahyudi, Manajemen, h. 47

${ }^{13}$ Ibid, h. 49-50
} 
kelemahan (Weakness). Kedua, analisis lingkungan eksternal memusatkan perhatiannya pada penganalisaan diluar organisasi yakni melihat peluang(Opportunity) dan ancaman (Threath). ${ }^{14}$

Berbagai sistem yang berada diluar organisasi itu disebut juga dengan faktor (lingkungan) eksternal yang meliputi ekonomi, politik, sosial, teknologi, demografi dan hukum. ${ }^{15}$ Mengenai bagaimana pengaruh faktor-faktor tersebut terhadap perusahaan organisasi) adalah sebagai berikut:

1) Faktor Ekonomi

Situasi perekonomian pada umumnya mempunyai pengaruh yang besar terhadap kehidupan dan perkembangan suatu perusahaan maupun perusahaan secara keseluruhan. Faktor-faktor ekonomi yang diperhatikan bukan hanya terbatas pada situasi ekonomi dalam negeri, tapi juga ekonomi internasional pada umumnya.

2) Faktor Politik

Faktor politik ini berkenaan dengan kebijaksanaankebijaksanaan pemerintah dibidang politik. Stabilitas politik dalam negeri dapat mengayomi keberadaan perusahaan yang beroperasi. Yang perlu diperhatikan misalnya peraturan-peraturan dan atau perundang- undangan yang baru dikeluarkan oleh pemerintah.

3) Faktor Sosial

Yang perlu diperhatikan dalam lingkungan sosial misalnya nilai-nilai sikap, keyakinan, pandangan hidup masyarakat yang dapat dibentuk oleh kebudayaan, ekologis, demografis, agama, pendidikan serta tehnisnya. Perubahan sosial dalam bentuk perubahan nilainilai dan sikap dapat mempengaruhi perilaku konsumen dalam melakukan pilihan ekonomisnya.

4) Faktor Teknologi

Perkembangan dan perubahan teknologi baru, mutlak perlu diperhatikan oleh perusahaan. Perkembangan teknologi ini bukan hanya terbatas pada penciptaan alat-alat produksi baru seperti mesin-mesin, tapi juga menyangkut teknik-teknik dalam proses produksi. Adanya penemuan teknologi baru dapat memberikan kesempatan-kesempatan berusaha baru, tapi dapat pula mengancam

14 Michael A. Hitt, Manajemen Strategis: Menyongsong Era Persaingan dan Globalisasi, ter. Armand Hediyanto (Jakarta: Erlangga, 1997 cet. I), h. 42

${ }^{15}$ Robinson Pearce, Manajemen Strategi, h. 93 
usaha-usaha lama. Misalnya, dengan semakin populernya pemakaian kalkulator elektronik, dapat mematikan alat hitung sempoa.

5) Faktor Demografi

Yang perlu diperhatikan dalam aspek demografis ini misalnya tingkat kesuburan, mortalitas, tingkat pertumbuhan penduduk, distribusi penduduk menurut umur, serta pertumbuhan penduduk.

6) Faktor Hukum

Yang perlu diperhatikan misalnya kewajiban-kewajiban ditinjau dari segi hukum, baik masa lalu, sekarang maupun yang akan dating. ${ }^{16}$

Dari berbagai lingkungan diatas, apabila adanya perubahan, tidak mustahil dapat memberikan kesempatan berusaha baru, tapi dapat pula mangancam kehidupan usaha lainnya. Selain itu, terdapat faktor internal yang meliputi, kondisi keuangan, struktur organisasi, kualitas dan kuantitas personil, fasilitas dan sarana, tujuan dan strategi masa lalu. Dengan memadukan dan memperhatikan kesempatankesempatan (O) dan ancaman-ancaman (T) yang berasal dari lingkungan eksternal, baik sekarang maupun ramalan masa datang, dengan berbagai kekuatan-kekuatan (S) dan kelemahan- kelemahan (W) yang berasal dari lingkungan internal barulah disusun suatu strategi yang mantap. Dalam internal bisnis, kegiatan tersebut dianggap sebagai pengenalan situasi yang disebut "SWOT analisis". Analisis SWOT ini singkatan dari Strength, Weakness, Oppourtunities dan Threath. ${ }^{17}$

Dalam melakukan analisis lingkungan eksternal yang terdapat beberapa faktor (ekonomi, politik, sosial, teknologi, demografi, dan hukum) ini diperlukan sebuah tehnik yang baik agar informasi yang didapat utuh. Beberapa tehnik antara lain:

1) Tehnik pengumpulan informasi lisan adalah informasi yang didapat dengan cara mendengar, baik itu secara formal maupun non formal.

2) Tehnik pengumpulan imformasi tertulis atau dokumentasi adalah apa yang diketahui dengan membaca informasi yang disediakan oleh orang lain untuk berbagai tujuan. Misalnya, informasi surat kabar tentang perekonomian, politik dan lain-lain.

16 Napa J Awat, Manajemen Strategi: Suatu Pendekatan Sistem, (Yogyakarta: Liberty, 1998)

${ }^{17}$ Ibid, h. 24 
3) Tehnik memata-matai (spionase) yaitu berusaha untuk mengumpulkan informasi tentang pesaing yang potensial atau sesungguhnya.

4) Tehnik pengamatan langsung. Manajer puncak atau orang yang ditunjuk melakukan pengamatan langsung kepasar yang menjadi sasaran produk/ jasa kita.

5) Tehnik peramalan secara formal adalah meramalkan semua faktor lingkungan. Misalnya mengenai pandangan masyarakat terhadap pelayanan pendidikan dan sebagainya. ${ }^{18}$

Dalam menyusun strategi seorang manajer mampu menilai mana yang merupakan ancaman/ peluang. Sebelumnya harus menilai dan mendiagnosa hasil dari berbagai informasi yang sudah didapat sebelum keputusan dibuat.

Analisis lingkungan internal digunakan untuk membangun kemampuan (kapabilitas) dalam mencapai keunggulan. Dengan demikian, analisis lingkungan internal akan mencakup analisis mangenai sumber daya, kapabilitas dan kompetensi. Tiga komponen tersebut antara lain:

1) Sumber daya

Sumber daya/ resources sering diartikan sebagai input yang dibutuhkan oleh lembaga untuk proses produksi. Proses produksi ini berkaitan dengan proses belajar mengajar untuk menciptakan siswa/siswi bisa menerima dengan baik materi yang diajarkan oleh guru. Secara sederhana sumber daya dibagi menjadi 3 kelompok meliputi Tangible resources, Intangible resources dan human resources. ${ }^{19}$

2) Kemampuan (kapabilitas)

Kemampuan adalah suatu kumpulan sumber daya yang menampilkan suatu tugas/aktivitas tertentu secara integrative. ${ }^{20}$ Untuk menentukan kapabilitas suatu organisasi/lembaga biasanya didasarkan kepada 2 pendekatan. Dua pendekatan ini dalam dunia perusahaan dikenal dengan pendidikan fungsional dan pendekatan rantai nilai (istilah perusahaan Value Chain).

18 Amirullah dan Sri Budi Cantika, Manajemen STrategi (Jogjakarta: Garaha Ilmu, 2000), h. 28.

${ }^{19}$ Setiawan Hari Purnomo dan Zulkieflimansyah, Manajemen Strategik: Sebuah pengantar (Jogjakarta: FEUI, 1999) h. 42

${ }^{20}$ Ibid, 43 
Pedidikan fungsional menentukan kapabilitas organisasi secara relatif terhadap fungsi-fungsi manajemen seperti pemasaran, keuangan, lembaga, SDM dan out put. Sedangkan pendidikan rantai nilai kapabilitas didasarkan pada serangkaian kegiatan yang berurutan yang merupakan sekumpulan aktifitas nilai yang dilakukan untuk mendesain, memasarkan, input-proses-out put untuk mendukung perkembangan lembaga sekolah.

3) Kompetensi Inti

Kompetensi inti adalah suatu ketrampilan dan teknologi yang integrasi yang memberikan kontribusi untuk melakukan kompetensi dengan lembaga non Islam. Secara singkat dapat dikatakan bahwa kompetensi inti adalah fungsi dari teknologi, proses dan hasil belajar. Jadi kompetensi inti seharusnya dimiliki ole banyak orang dalam suatu organisasi.

b. Strategi tingkat Korporasi

Apabila analisis lingkungan telah berhasil dilakukan bagaimana yang dipaparkan diatas berarti kita sudah berhasil menyelesaikan 50\% dari strategik. Sebab kecermatan mencocokkan peluang dan tantangan yang dihadapi dengan kekuatan dan kelemahan organisasi merupakan inti dari formulasi strategi yang tepat.

1) Strategi Induk

Penentuan visi dan misi organisasi bisa disebut juga strategi induk. Visi berasal dari bahasa latin 'vision' artinya melihat. ${ }^{21}$ Melihat komitmen pengaktualisasi yang tidak realitas menjadi kenyataan atau sering disebut cita-cita. Cita-cita mendorong pemilik sekolah ingin merealisasikan. Cita- cita adalah merupakan kebanggaan dan kebahagiaan. Oleh karena itu, visi adalah cara pandang yang menyeluruh dan futuristik terhadap pernyataan menjadi organisasi seperti apa dalam 5 tahun mendatang.

Syarat dalam menetapkan visi, sebab visi sulit difahami karena berada dibenak pendiri. Adapun beberapa syarat visi antara lain:

a) Harus mencakup segala hal.

b) Visi tersebut harus menciptakan rasa semangat, kekuatan dan komitmen bersama.

${ }^{21}$ Gabriel Amin Silalahi, Strategi Manajemen (Surabaya : CV Citra Media, 2003), h. 27. 
c) Tidak terlalu ideal tetapi visi tersebut realistis dan dapat dicapai serta dapat dipergunakan sebagai pedoman bagi semua aktifitas organisasi.

d) Diungkapkan secara spesifik dan realistis dan dinyatakan dengan keyakinan, sebab visi pencampuran nilai, arah dan tujuan yang akan memandu masa depan organisasi.

Misi merupakan pedoman untuk perumusan tujuan dan penyusunan strategi yang akan dipakai untuk mencapai tujuan yang telah diformulasikan. Misi sekolah yang jelas merupakan bagian terpenting dalam manajemen strategik, karena keberadaan misi yang dinyatakan secara formal biasanya membuat organisasi/sekolah akan berhasil.

Untuk itu diperlukan beberapa peraturan tertentu dalam menulis dan melaksanakan pernyataan misi yang diambil. Beberapa peraturan antara lain:

a) Jagalah agar pernyataan tetap sederhana. Tidak harus pendek tetapi sederhana.

b) Memungkinkan masukan dari seluruh SDM perusahaan (organisasi).

c) Orang luar bisa mendatangkan kejelasan dan perspektif yang segar kedalam proses penulisan pernyataan misi anda.

d) Susunan dan nada kata-kata seharusnya mencerminkam kepribadian perusahaan atau ingin menjadi apa perusahaan (organisasi) ini.

e) Berbagilah pernyataan misi dengan cara kreatif sebanyak mungkin dalam bahasa sebanyak yang diperlukan. Jagalah agar pernyataan misi tetap berada dihadapan setiap orang.

f) Mengandalkan pernyataan misi sebagai bimbingan. Tantanglah penyataan misi terus-menerus, dan nilailah karyawan dengan sebaik- baiknya apa mereka sudah mematuhi prinsip-prisipnya manajemen harus menyatakan dan menghayatinya. ${ }^{22}$

Dalam proses perumusan misi organisasi atau sekolah harus memperhatikan peraturan-peraturan di atas, dan kepala sekolah harus mempertimbangkan peraturan-masukan-masukan dari pihak-pihak yang berkepentingan terhadap orgnisasi. Pihak yang berkepentingan bisa dari dalam organisasi yang terdiri dari kepala sekolah, guru dan

22 Muh. Ismail Yusanto dan Muhammad Karebet Widjaja Kusuma, Manajemen Strategis: Perspektif Syariah 9Jakarta: Khairul Bayan, 2003), h. 60. 
kariyawan. Sedangkan dari luar terdiri dari masyarakat sekitar, komite sekolah. Masing-masing pihak ini menuntut kepala sekolah harus mampu mengkomodir semua kepentingan baik dari dalam maupun dari luar agar kepetingan tersebut tercermin dalam perumusan misi organisasi.

2) Strategi Umum

Strategik umum ini difokuskan dalam pembuatan strategi. Tahap pembuatan strategi adalah suatu tahap yang paling menantang sekaligus menarik dalam proses manajemen strategik. Strategi adalah sejumlah tindakan untuk membantu organisasi mencapai tujuan Menurut penulis berdasarkan beberapa buku, terdapat tiga variasi strategi, variasi tersebut sangat penting sebagai upaya mencapai tujuan organisasi. Adapun penjelasan ketiga variasi strategi sebagai berikut:

a) Strategi Organisasional

Strategi Organisasional memuat cara yang direncanakan untuk pengembangan organisasi. Misalnya, kolaborasi atau mengadakan kerjasama. Dalam strategi organisasional ini difokuskan untuk sosialisasi lembaga pendidikan.

b) Strategi Program

Strategi Program adalah bagaimana mengembangkan, memanajemen dan menyampaikan program/mensosialisasikan program. Misalnya, melalui reklame atau pamflet-pamflet dan lainlain.

c) Strategi Fungsional

Strategi ini berisi bagaimana memanaj administrasi dan mendukung kebutuhan yang mempengaruhi efisiensi dan efektivitas organisasi. Strategi fungsionalini sebagai suatu proses pengelolaan sumber daya organisasi. Untuk lembaga/institusi sekolah.

2. Implementasi Implementasi (Strategic Implementation)

Ada 4 (empat) elemen dasar yang digunakan oleh manajer untuk mengimplementasikan strategi. Empat elemen itu adalah struktur, kepemimpinan, kultur (budaya) dan sistem imbalan (motivasi). Uraian mengenai keempat elemen tersebut adalah sebagaui berikut:

a. Struktur Organisasi

Dalam mengimplementasi strategi lelalui struktur organisasi berguna untuk mengkomunikasikan kegiatan-kegiatan/tugas bawahan. Struktur organisasi adalah sebagai suatu sistem/jaringan kerja terhadap tugas-tugas, sistem pelaporan dan komunikasi yang 
menghubungkan secara bersama pekerjaan individual dan kelompok. ${ }^{23}$

Oleh karena itu, sebuah struktur organisasi hendaknya mengalokasikan pekerjaan melalui bagian-bagian pekerjaan dan menyediakan koordinasi dari hasil-hasil kinerja sehingga sasaran organisasi terlaksana dengan baik.

Untuk struktur organisasi yaitu menurut penulis, menggunakan struktur organisasi lini-staf karena, pembagian tugas yang begitu jelas dan memberikan kesempatan kepada karyawan dan guru untuk mengembangkan dirinya.

b. Kepemimpinan Organisasi

Kepemimpinan organisasi, suatu konsep yang merupakan satu elemen penting dari implementasi strategi yang efektif maka, struktur organisasi memberikan kerangka menyeluruh bagi implementasi strategi. Kepemimpinan dan kultur organisasi merupakan fenomena yang saling bergantung. Setiap aspek dari kepemimpinan akhirnya membantu membentuk kultur organisasi. Sebaliknya, kultur organisasi yang sudah ada dapat sangat mempengaruhi efektifitas seorang pemimpin. Eratnya kesaling bergantungan ini akan terlihat jelas.

c. Kultur Organisasi

Kultur (budaya) organisasi adalah sekumpulan asumsi penting (seringkali tidak diungkapkan) yang dianut oleh semua anggota suatu organisasi. Setiap organisasi memiliki budaya sendiri. Kultur suatu organisasi serupa dengan kepribadian seseorang tak wujud (intangible) tetapi selalu ada yang memberikan makna, arah dan dasar bertindak.

d. Sistem Imbalan (motivasi)

Pelaksanaan strategik pada akhirnya bergantung pada anggota organisasi secara individual, utamanya para manajer kunci. Dan memotivasi serta menghargai prestasi individu dan unit organisasi yang baik merupakan bahan penting dalam implementasi strategi yang efektif. Jika pencapaian strategi merupakan prioritas puncak, maka system imbalan harus secara jelas dan erat terkait dengan prestasi strategic. $^{24}$

\footnotetext{
${ }^{23}$ Amirullah, Manajemen, h. 157

${ }^{24}$ Robinson Pearce, Manajemen, h. 429
} 


\section{Evaluasi (pengawasan) Strategik}

Setelah strategi selesai dirumuskan dan berhasil disini, masih ada satu pekerjaan lagi yang harus dilakukan yaitu evalausi strategik. Yang dimaksudkan dengan evaluasi strategik disini adalah usahausaha untuk memonitor hasil-hasil dari pembuatan perumusan (formulasi) dan penerapan (implementasi) strategi termasuk mengukur kinerja dan organisasi, serta mengambil langkah-langkah perbaikan jika diperlukan. ${ }^{25}$ Pengawasan adalah tahap proses manajerial mengenai pemeliharaan kegiatan organisasi dalam batas-batas yang diizinkan yang diukur dari harapa-harapan. Pengawasan organisasi itu saling berkaitan erat dengan perencanaan. ${ }^{26}$

Adapun mengenai apa unsur-unsur dan bagaimana proses pengawasan itu, penulis akan menguraikan sebagai berikut:

a. Unsur Pengawasan

Ada 4 (empat) unsur pokok yang lazim terdapat dalam semua sistem pemgawasan. Unsur-unsur ini tetap berlaku bagaimanapun tingkat kecanggihan sistem itu. 4 unsur adalah sebagai berikut:

1) Suatu karakteristik /kondisi yang di kendalikan (diawasi)

2) Sensor, yakni metode untuk mengukur karakteristik /kondisi diatas.

3) Kompetitor, yakni membandingkan antar yang aktual dengan standar, serta menilai perbedaan-perbedeaan yang terjadi.

4) Efektor, yakni tindakan mempengaruhi perubahan dalam sistem tersebut untuk disesuaikan dengan karakteristik /standar yang diinginkan. $^{27}$

b. Proses Pengawasan

Dengan dibandingkan prestasi yang sesugguhnya dengan rencana, maka dihasilkan umpan balik untuk penyesuaian beban kerja dengan alokasi sumber daya jenis perbandinga ini terutama mengenai alat-alat yang dipakai untuk mencapai tujuan. Dibuat pula membandingkan antara prestasi sesungguhnya dengan rencana program semula. Pada tahap ini, informasi diumpan-balikkan ketahap perencanaan program, dan untuk perbandingan dengan sasaran semula. Akhirnya, perbandingan ini membawa kepada pengukuran tujuan yang ada atau penyesuaian untuk masa depan.

${ }^{25}$ Karhi Nisjar, Manajemen, h. 86

${ }^{26}$ Fremont E Kast, Organisasi, h. 729

${ }^{27}$ Fremont E Kast, Organisasi, h. 733 
Selanjutnya, dilakukan penetapan standar yang diinginkan. Seorang manajer perlu melakukan tiga kegiatan sebagai berikut:

1) Pengukuran pelaksanaan (kinerja karyawan).

2) Membandingkan hasil kegiatan pelaksanaan dengan standar yang telah ditetapkan.

3) Melakukan tindakan koreksi apabila terjadi penyimpangan antara hasil yang dicapai dalam operasi dengan standar.

\section{Kepala Sekolah}

Kepala sekolah merupakan salah satu komponen pendidikan yang paling berperan dalam meningkatkan kualitas pendidikan. Seperti diungkapkan Supriadibahwa: "Erat hubungannya antara mutu kepala sekolah dengan berbagai aspek kehidupan sekolah sepertidisiplin sekolah, iklim budaya sekolah, dan menurunnya perilaku peserta didik." 28

Dalam pada itu kepala sekolah bertanggung jawab atas manajemenpendidikan secara mikro, yang secara langsung berkaitan dengan prosespembelajaran disekolah. Sebagaimana dikemukakan dalam pasal 12 ayat 1PP 28 tahun 1990 bahwa: "Kepala sekolah bertanggung jawab atas penyelengggaraan kegiatan pendidikan, administrasi sekolah, pembinaaantenaga kependidikan lainnya dan pendayagunaan serta pemeliharaaan sarana prasarana ${ }^{29}$.

Wahjosumidjo mendefinisikan Kepala Sekolah sebagai seorang tenaga fungsional guru yang diberi tugas untuk memimpin suatu sekolah dimana diselenggarakan proses belajar mengajar, atau tempat dimana terjadi interaksi antara guru yang memberi pelajaran dan murid sebagai penerima pelajaran ${ }^{30}$.

Kepala sekolah adalah sosok yang diberikepercayaan dan kewenangan oleh banyak orang (anak buah) untuk membawa sekolah ke arah tujuan yang ingin dicapai. Kepercayaan yang diberikan oleh

28 Hasmayanti, Yanti. "Pengaruh Efektivitas Kepemimpinan Kepala Sekolah Dan Motivasi Kerja Terhadap Kompetensi Guru (Studi pada Jurusan Bisnis dan Manajemen Sekolah Menengah Kejuruan Negeri dan Swasta di Kabupaten Sumedang)." Jurnal Manajerial 9, no. 18 (2011)

29 Sulistiya, Mukhamad. "Pengaruh Kepemimpinan Kepala Sekolah Terhadap Kinerja Guru." Ekonomi IKIP Veteran Semarang 1, no. 2 (2013).

${ }^{30}$ Karweti, Engkay. "Pengaruh kemampuan manajerial kepala sekolah dan faktor yang mempengaruhi motivasi kerja terhadap kinerja guru SLB di Kabupaten Subang." Jurnal Penelitian Pendidikan 11, no. 2 (2010): 77-89. 
anak buah ini adalah didasarkan pada beberapa aspek yang dimiliki oleh kepala sekolah dan diharapkan dapat menjadi modal untuk membawa pada keberhasilan bersama ${ }^{31}$.

Pidarta mengemukakan tiga macam ketrampilan yang harus dimiliki oleh kepala sekolah untuk menyukseskan kepemimpinannya. Ketiga ketrampilan tersebut adalah ketrampilan konseptual, yaitu ketrampilan untuk memahami dan mengoperasikan organisasi; ketrampilan manusiawi, yaitu ketrampilan untuk bekerjasama, memotivasi dan memimpin; serta ketrampilan. ${ }^{32}$

\section{Sekolah Unggul}

Sekolah/Madrasah Unggulan adalah sebuah madrasah program unggulan yang lahir dari sebuah keinginan untuk memiliki sekolah/madrasah yang mampu berprestasi di tingkat nasional dan dunia,dalam penguasaan ilmu pengetahuan, keterampilan dan teknologi yang ditunjang oleh akhlakul karimah. Untuk mencapai keunggulan tersebut, maka masukan (input), proses pendidikan, guru dan tenaga kependidikan, manajemen, layanan pendidikan, serta sarana penunjangnya harus diarahkan untuk menunjang tercapainya tujuan tersebut.

Sekolah/Madrasah unggulan perlu ditunjang dengan tenaga pendidik yang perofesional, saran yangmemadai, kurikulum yang inovatif, ruang kelas atau pembelajaran yang representatif sehingga dapat mendorong terciptanya pembelajaran yang efektif dan efisien dan menghasilkan

lulusan yang berkualitas.

Di sisi lain, Bafadhal mengemukakan bahwa untuk mencapai sekolah/madrasah yang unggul dituntut adanya fasilitas dan dana yang memadai, akan tetapi tidak semua sekolah atau madrasah dapat memenuhinya. Secara teknis, pengembangan madrasah unggulan menuntut adanya tenaga profesional dan fasilitas yang memadai sehingga dampaknya dibutuhkannya biaya belajar yang tidak sedikit.

Menurut Terry McLaughlin "Sekolah unggul adalah sekolah yang mampu membawa setiap siswa mencapai kemampuannya secara

${ }^{31}$ Hakim, Abdul. "Model pengembangan kewirausahaan sekolah menengah kejuruan (SMK) dalam menciptakan kemandirian sekolah." Jurnal 4, no. 1 (2010).

${ }^{32}$ Ibid, h. 736 
terukur dan mampu menunjukkan prestasinya tersebut"33. Sedangkan Jaap Scheerens menyebutkan sekolah yang Unggul/efektif mempunyai lima ciri penting yaitu;(1) kepemimpinan yang kuat;(2) penekanan pada pencapaian kemampuan dasar; (3) adanya lingkungan yang nyaman; (4) harapan yang tinggi pada prestasi siswa; (5) dan penilaian secara rutin mengenai program yang dibuat siswa ${ }^{34}$.

Istilah sekolah unggul pertama kali diperkenalkan oleh mantan Menteri Pendidikan dan Kebudayaan (Mendikbud) Wardiman Djojonegoro, tahun 1994. Istilah sekolah unggul lahir dari satu visi yang jauh menjangkau ke depan, wawasan keunggulan. Menurut Wardiman, selain mengharapkan terjadinya distribusi ilmu pengetahuan, dengan membuat sekolah unggul di tiap-tiap propinsi, peningkatan SDM menjadi sasaran berikutnya. Lebih lanjut, Wardiman menambahkan bahwa kehadiran sekolah unggul bukan untuk diskriminasi, tetapi untuk menyiapkan SDM yang berkualitas dan memiliki wawasan keunggulan ${ }^{35}$.

Departemen Pendidikan dan Kebudayaan telah menggariskan bahwa sekolah unggulan adalah sebuah institusi pendidikan yang memiliki ciri utama atau karakteristik sebagai berikut:

1. Input diseleksi secara ketat dengan kriteria tertentu dan melalui prosedur yang dapat dipertanggungjawabkan. Kriteria yang dimaksudkan adalah: a) Prestasi belajar superior dengan indikator anggka rapot, nilai EBTANAS atau UPM Murni dan hasil tes prestasi akademik; b) Skor psikotes yang meliputi intlegensi dan kreatifitas; c) Tes fisik jika diperlukan.

2. Sarana dan prasarana yang menunjang untuk memenuhi kebutuhan belajar siswa serta menyalurkan minat dan bakatnya, baik dalam kegiatan intrakurikuler maupun ekstrakurikuler.

${ }^{33}$ Sumarsono, Raden Bambang. "Upaya Peningkatan Mutu Sekolah melalui Penguatan Peran Kepemimpinan Pembelajaran oleh Kepala Sekolah." Tersedia secara online di: http://ap. fip. um. ac. id/wp-content/uploads/2016/03/41-RadenBambang-Sumarsono. pdf [diakses di Ciputat, Indonesia: 25 Januari 2017] (2016).

${ }^{34}$ Jabar, Cepi Safruddin Abd. "Pencapaian Keunggulan pada SMA negeri dan swasta berkategori unggul di Kota Bandung." Jurnal Penelitian Pendidikan 12, no. 2 (2011): 86-93.

35 Mujtahid, Mujtahid. "Pengembangan Madrasah dan Sekolah Islam Unggulan." el-hikmah 1 (2013). 
3. Lingkungan belajar yang kondusif untuk berkembangnya potensi keunggulan menjadi keunggulan yang nyata baik lingkungan fisik maupun sosial psikologis.

4. Guru dan tenaga kependidikan yang menangani harus unggul baik dari segi penguasaan materi pelajaran, metode mengajar, maupun komitmen dalam melaksanakan tugas.

5. Kurikulumnya diperkaya dengan pengembangan dan improvisasi secara maksimal sesuai dengan tuntunan belajar peserta didik yang memiliki kecepatan belajar serta motivasi belajar yang lebih tinggi dibandingkan dengan siswa seusianya.

6. Kurun waktu lebih lama dibandingkan sekolah lain.

7. Proses belajar harus berkualitas dan hasilnya dapat dipertanggung jawabkan, baik kepada siswa, lembaga maupun masyarakat.

8. Sekolah unggul itu tidak hanya memberikan manfaat kepada peserta didik di sekolah tersebut, tetapi harus memiliki resonansi sosial terhadap lingkungan sekitar.

9. Pembinaan kemampuan kepemimpinan yang menyatu dalam keseluruhan sistem pendidikan siswa melalui praktek langsung dalam kehidupan sehari-hari bukan sebagai materi pelajaran.

10.Nilai lebih sekolah unggul terletak pada perlakuan tambahan diluar kurikulum, program pengayaan dan perluasan, pengajaran remidial, pelayanan, bimbingan dan konseling yang berkualitas, pembinaan kreatifitas dan disiplin.

Menurut Djoyonegoro ciri-ciri sekolah unggul adalah sekolah yang memiliki indikator, yaitu: (1) prestasi akademik dan nonakademik di atas rata-rata sekolah yang ada di daerahnya; (2) sarana dan prasarana dan layanan yang lebih lengkap; (3) sistem pembelajaran lebih baik dan waktu belajar lebih panjang; (4) melakukan seleksi yang cukup ketat terhadap pendaftar; (5) mendapat animo yang besar dari masyarakat, yang dibuktikan banyaknya jumlah pendaftar dibanding dengan kepasitas kelas; (6) biaya sekolah lebih tinggi dari sekolah disekitarnya.

\section{Manajemen Sekolah Unggulan}

Dalam konsep sekolah efektif, manajemen kelembagaan sekolah merupakan tinjauan sekolah dari sudut penataan oleh kepala sekolah terhadap bidang-bidang garapan sekolah, antara lain: kesiswaan, ketenagaan, kurikulum, sarana dan prasarana, keuangan, dan kemitraan sekolah dengan masyarakat. 
Secara umum, sebuah sekolah dapat dikategorikan unggul harus meliputi tiga aspek dalam manajerial. Ketiga aspek tersebut adalah:

\section{Input (masukan)}

Input (masukan) sekolah adalah segala masukan yang dibutuhkan sekolah untuk terjadinya pemrosesan guna mendapatkan output yang diharapkan. Input sekolah merupakan bahan-bahan yang diperlukan untuk mencapai pembentukan manusia yang disebut manusia seutuhnya

Pendidikan tidak boleh diartikan hanya sebagai proses transfer ilmu saja, namun juga harus diartikan sebagai upaya membantu siswa untuk mampu mengenal diri dan lingkungannya. Daniel Goleman, dalam bukunya, menyebutkan bahwa kemampuan mengenal diri dan lingkungannya adalah kemampuan untuk melihat secara objektif atau analisis, dan kemampuan untuk merespon secara tepat, yang membutuhkan kecerdasan otak (IQ) dan kecerdasan emosional (EQ). Di samping itu, kecerdasan spiritual (SQ) calon siswa hendaknya dapat terukur saat seleksi siswa baru. Dengan demikian, tes seleksi siswa baru hendaknya dapat mengukur ketiga aspek kecerdasan atau bahkan dapat mengukur berbagai kecerdasan atau multy intellegence.

\section{Proses}

Proses belajar-mengajar sekolah unggul ini setidaknya berkaitan dengan kemampuan guru, fasilitas belajar, kurikulum, metode pembelajaran, program ekstrakurikuler, dan jaringan kerjasama. Komptensi guru yang memungkinkan untuk mengembangkan suatu lembaga pendidikan yang unggul adalah: ${ }^{36}$

1) Kompetensi penguasaan mata pelajaran

2) Kompetensi dalam pembelajaran

3) Kompetensi dalam pembimbingan

4) Kompetensi komunikasi dengan peserta didik

5) Kompetensi dalam mengevaluasi

36 Ahmad Zayadi, Desain Pengembangan Sekolah/ Madrasah, (Jakarta: Dirjen Kelembagaan Pendidikan Islam Depag, 2005), h. 57 


\section{Kesimpulan}

Kemampuan memahami kondisi sekolah luar-dalam merupakan tuntutan bagi para pemimpin sekolah. Hal ini diperlukan untuk mengenal secara mendalam segala potensi sekolah yang dapat dikembangkan, dibenahi, atau diberikan perlakuan tertentu. Tujuannya untuk memastikan bahwa sekolah selalu menghadapi segala kondisi yang tidak terkirakan. Jika konsolidasi ke dalam telah berjalan, maka pemimpin sekolah memindahkan pandangan ke dunia luar, dimana masyarakat sebagai pelanggan berada. Cara pandang ini akan membawa sekolah pada komitmen mutu dan perbaikan secara berkelanjutan. Sisi lain yang tidak kalah penting adalah mengawasi kondisi lingkungan secara luas dan dapat membaca kondisi pesaing, sehingga sekolah dapat membuat perbedaan. 


\section{Daftar Pustaka}

Akdon, Strategic Management for Educational Management. (Bandung: Alfabeta 2011)

Amirullah dan Sri Budi Cantika, Manajemen STrategi (Jogjakarta: Garaha Ilmu, 2000)

Awat, Napa J., Manajemen Strategi: Suatu Pendekatan Sistem, (Yogyakarta: Liberty, 1998)

Fahmi, Irham, Manajeman Strategis, (Bandung : Alfabeta, 2015)

Hasmayanti, Yanti. "Pengaruh Efektivitas Kepemimpinan Kepala Sekolah Dan Motivasi Kerja Terhadap Kompetensi Guru (Studi pada Jurusan Bisnis dan Manajemen Sekolah Menengah Kejuruan Negeri dan Swasta di Kabupaten Sumedang)." Jurnal Manajerial 9, no. 18 (2011)

Hitt, Michael A., Manajemen Strategis: Menyongsong Era Persaingan dan Globalisasi, ter. Armand Hediyanto (Jakarta: Erlangga, 1997 cet. I)

Hakim, Abdul. "Model pengembangan kewirausahaan sekolah menengah kejuruan (SMK) dalam menciptakan kemandirian sekolah." Jurnal 4, no. 1 (2010).

Jabar, Cepi Safruddin Abd. "Pencapaian Keunggulan pada SMA negeri dan swasta berkategori unggul di Kota Bandung." Jurnal Penelitian Pendidikan 12, no. 2 (2011)

Karweti, Engkay. "Pengaruh kemampuan manajerial kepala sekolah dan faktor yang mempengaruhi motivasi kerja terhadap kinerja guru SLB di Kabupaten Subang." Jurnal Penelitian Pendidikan 11, no. 2 (2010): 77-89.

Muchlis, Abdul, Implementasi Manajeman Strategi Dalam Upaya Peningkatan Mutu Pendidikan, (Fakultas Dakwah: Jurusan Manajeman Dakwah)

Mujtahid, Mujtahid. "Pengembangan Madrasah dan Sekolah Islam Unggulan." el-hikmah 1 (2013).

Nogi S, Hassel, Tangkilisan, Manajemen Modern untuk Sektor Public, (Yogyakarta: Balairung, 2003)

Purnomo, Setiawan Hari dan Zulkieflimansyah, Manajemen Strategik: Sebuah pengantar (Jogjakarta: FEUI, 1999)

Siagian, Sondang P, Manajemen Strategik (Jakarta: Bumi Aksara, 2001) 
Silalahi, Gabriel Amin, Strategi Manajemen (Surabaya : CV Citra Media, 2003)

Sulistiya, Mukhamad. "Pengaruh Kepemimpinan Kepala Sekolah Terhadap Kinerja Guru." Ekonomi IKIP Veteran Semarang 1, no. 2 (2013)

Sumarsono, Raden Bambang. "Upaya Peningkatan Mutu Sekolah melalui Penguatan Peran Kepemimpinan Pembelajaran oleh Kepala Sekolah." Tersedia secara online di: http://ap. fip. um. ac. id/wp-content/uploads/2016/03/41-Raden-BambangSumarsono. pdf [diakses di Ciputat, Indonesia: 25 Januari 2017] (2016).

Umar, Husein, Desain Penelitian Manajemen Strategik (Jakarta: PT. Raja Grafindo Persada. 2010)

Yusanto. Muh. Ismail dan Muhammad Karebet Widjaja Kusuma, Manajemen Strategis: Perspektif Syariah 9Jakarta: Khairul Bayan, 2003)

Zayadi, Ahmad, Desain Pengembangan Sekolah/ Madrasah, (Jakarta: Dirjen Kelembagaan Pendidikan Islam Depag, 2005) 